«Buttermilch!» kreischte Abraxas. «Mir scheint, du bist vollständig übergeschnappt! Was willst du denn noch alles regnen lassen? Wäscheklammern vielleicht? Oder Schustemägel? Wenn es doch wenigstens Brotkrümel oder Rosinen wären!» [5] - Кисляк! - вигукнув Абраксас. - Ти 3 глузду з'їхала! Що ти нам іще начаклуєш? Може, прищепок для білизни? Чи шевських гвіздків? Хоч би вже там з неба сипалися крихти хліба чи родзинки! [4, с. 7].

Отже, у казці О. Пройслер використовує практично всі тропи: епітет, порівняння, метафору, метонімію, гіперболу, оксиморон, іронію. У літературно-художньому перекладі В. Василюку вдалося відтворити не тільки зміст і форму першотвору, а й передати авторський задум, характери персонажів, авторський стиль, художні засоби і стилістичні фігури твору мови-оригіналу.

\title{
Література:
}

1. Ганич Д. І., Олійник І. С. Словник лінгвістичних термінів. Київ : Вища школа, 1985. 360 с.

2. Крайнікова Т. Мова художнього твору. Київ : Дніпро, 2002. 150 с.

3. Плющ М. Я., Бевзенко С. П., Грипас Н. Я. Сучасна українська літературна мова: Підручник. Київ : Вища школа, 2003. 430 с.

4. Пройслер О. Мала Баба Яга. Водяничок / Перекл. 3 нім. і передм. В. Т. Василюка. Київ : Веселка, 1992. С. 5-68.

5. Preußler O. Die Kleine Hexe. URL: https://www.rulit.me/books/diekleine-hexe-download-304608.html

DOI https://doi.org/10.30525/978-9934-26-039-1-75

\section{СПОСОБИ ПЕРЕКЛАДУ РЕАЛІЙ У РОМАНІ ДЖЕЙН ОСТІН «НОРТЕНГЕРСЬКЕ АБАТСТВО»}

\author{
Нікіфорова Т. В. \\ магістрантка спеиіальності «Філологія» \\ Івано-Франківського національного технічного університету \\ нафти і газу \\ м. Івано-Франківськ, Украӥна
}

Слова-реалії - це своєрідні коди, які відображають національні особливості певного народу. Оскільки зараз ми спостерігаємо процес злиття культур, то дуже важливо звертати увагу на культурно марковану лексику. Такі слова допомагають читачеві відчути характерні риси 
конкретного етносу, про який розповідає автор. Це зумовило вибір теми дослідження.

С різні способи, щоб відтворити реалію. Українська філологиня Роксолана Зорівчак пропонує перекладати реалії за допомогою таких способів: 1) транскрипції (транслітерації); 2) гіперонімічного перейменування; 3) дескриптивної перифрази; 4) комбінованої реномінації; 5) калькування; 6) транспозиції на конотативному рівні; 7) методу уподібнення; 8) контекстуального розтлумачення реалій; 8) підбору ситуативного відповідника [2]. Андрієнко Т. П. зазначає, що, відтворюючи реалію, перекладач може обрати стратегію одомашнення або очуження [1, с. 12]. На нашу думку, ці стратегії викривляють зміст твору, оскільки одомашнення реалії може перенести події, які відбуваються, в іншу країну, а очуження зробить текст незрозумілим для непідготовленого читача.

Розгляньмо основні способи перекладу реалій у романі Джейн Остін «Нортенгерське абатство». Перший спосіб перекласти - метод транскрибування. Він передбачає, що звукову форму слова передають за допомогою засобів мови-перекладу, наприклад, Tunbridge - Танбридж (район у графстві Кент [5]). У перекладі цієї реалії увагу звертають на іiі вимову в англійській мові. Оскільки такий вид реалій не передає ніякої додаткової інформації, то їх не потрібно роз'яснювати. Якщо реалія позначає особливості культури, то транскрипція робить ії незрозумілою для читача, наприклад, squire - сквайр (раніше чоловік, який володів більшою частиною землі навколо села [5]). Відповідник «сквайр» у тексті перекладу не відображає поняття, яке хотіла висвітлити авторка. Щоб не відволікати читача приміткою і не переривати цілісну картину тексту, ми пропонуємо використати описовий зворот «великий землевласник».

Слід зазначити, що між транскрипцією та транслітерацією існує незначна відмінність. Використовуючи цей спосіб, перекладач відтворює графічну систему мови-оригіналу засобами мови-перекладу. Наприклад, lord - лорд (людина, яка має високе звання в дворянстві, наприклад, граф, віконт чи маркіз [5]), baronet - баронет (людина, яку отримала статус лицаря [5]). На нашу думку, реалії передали правильно, тому що це заглиблює читача в атмосферу суспільства тих часів. Оскільки ці слова $є$ поширеними у мовленні, то в читача немає виникнути проблем із розумінням тексту. У цьому випадку можна додати примітку, а читач вже сам вирішить, чи потрібна йому додаткова інформація про реалію.

Також реалії можна передавати за допомогою калькування. Калькування - це буквальний переклад, коли використовують перше 
значення слова. Наприклад, реалію tea-room відображають за допомогою словосполучення чайна кімната. В англійській мові це слово позначає невелику кімнату, де подають напої та невеликі страви, такі як чай та тістечка [5]). Ми вважаємо, що калькування не змінює значення цієї реалії, тому такий спосіб можна використовувати у перекладі.

У деяких випадках перекладач поєднує метод калькування та транскрибування. У тексті зазвичай такий прийом використовують у перекладі назв об'єктів архітектури, наприклад, Blaize Castle Блейзський замок. Першу частину реалії перекладач транскрибує та надає їй ознаки прикметника, тобто суфікс «-ськ-« та закінчення «-ий», а до другої - добирає відповідник. Цей спосіб, на нашу думку, $є$ ефективним, тому що так ми зберігаємо частину оригінальної назви i водночас даємо читачеві, який не знає англійську мову, зрозуміти, що тип цієї будівлі - замок.

Ще один спосіб перекласти реалію - дескриптивна перифраза. Цей спосіб передбачає заміну реалії описовим зворотом, наприклад, curricle - парний двоколісний екіпаж. В англійські мові «сurricle»-це двоколісна відкрита карета, яку тягнуть два коні [5]. Ми можемо зробити висновок, що у такий спосіб перекладач детально описав реалію, щоб читач якомога краще зрозумів іï значення. Це допомагає точно передати значення і зберегти цілісність тексту. Якщо зловживати цим способом, то у тексті буде забагато зайвих конструкцій і він стане нецікавим для читача.

Також реалії можна відтворювати за допомогою гіперонімічного перекладу. Цей спосіб передбачає заміну вужчого поняття ширшим. Його часто використовують у перекладі художніх текстів, оскільки він відображає основне значення реалії та сприяє ії розумінню читачем. Наприклад, scullery - буфетна. В англійські мові іменник «scullery»- це кімната біля кухні, особливо у великому старому будинку, де миють каструлі та чистять овочі для приготування їі [5]. В українській мові «буфетна» - це кімната у старовинних будинках, палацах, де готували закуски, напої та зберігали посуд. На нашу думку, таке перекладацьке рішення є виправданим, бо іменники мають подібне значення, що дає читачеві змогу зрозуміти основне призначення такої кімнати.

У перекладі реалій можна використовувати метод уподібнення. У такий спосіб ми передаємо реалію за допомогою понять, відомих українському читачеві, наприклад, clogs - черевики (вид взуття, верхня частина якого виготовлена з шкіри, а нижня - 3 дерева [5]). У цьому прикладі перекладач використовує відповідник «черевики», який в українській мові означає «вид невисокого взуття переважно на шнурках 
або гудзиках». Порівнявши ці два визначення, ми виявили, що український еквівалент не відповідає англійській реалії. Оскільки романи задовольняють естетичні потреби читача, то, ми вважаємо, що у цьому випадку значенням реалії можна знехтувати, щоб не обтяжувати текст описовим зворотом.

Іноді перекладач використовує контекстуальне розтлумачення реалій, тобто про їх значення ми дізнаємось із найближчого контексту. Наприклад, «...they followed their chaperones, arm in arm, into the ballrooт...» [4] (...юні леді пішли під руку вслід за старшими до бальної зали...) [3]. Chaperone - літня або заміжня жінка, яка супроводжує або контролює молоду незаміжню жінку [5]. Оскільки значення реалії можна зрозуміти 3 контексту, то перекладач вирішив не повторюватись i вказати, що молодих дівчат супроводжували старші жінки.

Також у тексті ми виявили випадки, коли перекладач зберігає реалії мовою оригіналу. Реалія «tete-a-tete» - це неформальна приватна розмова між двома людьми, особливо друзями [5]. Ми вважаємо, що можна зберігати реалію в оригіналі, оскільки вона є загальновідомою, але для цілісності тексту краще іiі перекласти, використавши дескриптивну перифразу «приватна розмова».

Отже, переклад реалій - це дуже відповідальний процес, тому що можна дуже легко змінити зміст тексту. Дослідивши роман Джейн Остін «Нортенгерське абатство», ми виявили 174 реалії. Найчастіше перекладач використовує транскрипцію (транслітерацію) реалій 83 випадки (47,8\%). Також застосовано калькування 29 разів $(16,7 \%)$, гіперонімічне перейменування - 26 (14,8\%), дескриптивну перифразу 13 (7,5\%), уподібнення - 10 (5,7\%), введення неологізму - 10 (5,7\%), контекстуальний переклад - $1(0,6 \%)$, нульовий переклад - $1(0,6 \%)$, перенесення реалії мовою оригіналу $-1(0,6 \%)$.

\section{Література:}

1. Андрієнко Т. П. Стратегії відтворення культурно-специфічних концептів і сценаріїв у перекладі художнього дискурсу. Проблеми семантики, прагматики та когнітивної лінгвістики. 2012. Вип. 21. C. 10-18. URL: http://nbuv.gov.ua/UJRN/psptkl_2012_21_4

2. Зорівчак Р. П. Реалія і переклад. Вид-во при Львівському держ. ун-ті, Львів. 1989. 216 с.

3. Остін Дж. Нортенгерське абатство. Фоліо, 2014. URL: https://docs.google.com/viewer?url=http\%3A\%2F\%2Fshron1.chtyvo. org.ua\%2FJane_Austen\%2FNortenherske_abatstvo.pdf 
4. Austen, J. Northanger Abbey. URL: https://www.gutenberg.org/files/ 121/121-h/121-h.htm

5. Cambridge Advanced Learner's Dictionary. URL: https://dictionary.cambridge.org/dictionary/english/

DOI https://doi.org/10.30525/978-9934-26-039-1-76

\title{
ПОЕТИЧНІ ПЕРЕКЛАДИ В. БРЮСОВА (НА МАТЕРІАЛІ АНГЛІЙСЬКОЇ ПОЕЗІї)
}

\author{
Палій К. В. \\ кандидат філологічних наук, \\ старший викладач кафедри германської філологї та перекладу \\ Національного університету «Полтавська політехніка \\ імені Юрія Кондратюка» \\ Воробйова О. С. \\ кандидат філологічних наук, \\ доиент кафедри германської філології та перекладу \\ Національного університету «Полтавська політехніка \\ імені Юрія Кондратюка» \\ Астахова C. A. \\ викладач кафедри германської філологї̈ та перекладу \\ Національного університету «Полтавська політехніка \\ імені Юрія Кондратюка» \\ м. Полтава, Україна
}

Валерій Якович Брюсов не лише відомий поет, прозаїк, літературознавець, теоретик вірша, критик, історик, а й сміливий перекладачноватор, який збагатив і тематику, i стилістику, і метрику сучасної поезії. В. Брюсов багато займався поетичними перекладами, він відкрив читачеві творчість Еміля Верхарна, був першим перекладачем віршів Поля Верлена, всесвітньо відомі переклади В. Брюсова творів Е. По, Ромена Роллана, Моріса Метерлінка, Віктора Гюго, Ж. Расіна, Мольєра, Дж. Байрона, Оскара Уайльда, Й. Гете, Вергілія та ін.

Слід зазначити, що не все в його перекладах було рівноцінно, існувало дуже багато протиріч: він намагався дійти до меж можливого в 